\title{
Digital Literacy and Utilization of ICT Resources for Teaching and Learning amongst Secondary School Teachers in Anambra State, Nigeria: Implications amidst Covid-19 Pandemic
}

\author{
Genevive Anulika Abazie ${ }^{1}$ \\ Department of Educational Leadership and Management, Faculty of Education, \\ Southwest University No. 2 Tiansheng Road, Beibebi District, Chongqing 400715, China \\ E-mail: geneviveabazie@gmail.com
}

\begin{abstract}
The importance of digital learning was made abundantly clear when schools across the world transited from the traditional classroom learning to on-line learning as a result of the Covid-19 pandemic. The pandemic showed the world that we were not as prepared for digital learning as we thought. Teachers were not familiar with the issues brought on by digital learning and many students did not know how to properly employ available technology. This research, assess the level of digital literacy and use of ICT resources by secondary school teachers in Awka South, Anambra State. Specifically, the objectives of the study were to find out if the teachers in the secondary schools in Awka South LGA are digital literate, the extent of teacher's awareness of ICT resources, find out if the teachers utilize ICT resources in curriculum delivery and examine the various problems encountered by the teachers in the use of e-learning resources, and as well explore what problems this poses to teaching and learning in the time of Covid-19. The study adopted a survey method. A total of two hundred and forty (240) senior class teachers were selected from nineteen (19) public secondary schools in Awka South. A formal questionnaire was constructed and used to collect data from a target group of 240 respondents as adopted. Descriptive analytical techniques such as frequency, percentage, mean and standard deviation were applied to analyze and interpret the data. The outcomes of such analysis are presented on tables. The result of the study showed that a number of the teachers are not digitally literate and are not aware of ICT and e-learning resource, which led to the disruption of teaching and learning during the Covid-19 pandemic. A major factor which contributed to inadequate awareness of ICT among teachers is lack of teacher's professional development on ICT awareness and limited support and motivation from school leaders and the government. The few who are digital literate and could access ICT resources are confronted with problems such as lack of internet facilities, poor electricity, poor network, poor management and high cost of ICT facilities and internet data bundles. The study recommended provision of ICT facilities in secondary schools, the installation of internet facilities in secondary schools, subsidized data bundles, provision of e-libraries and creation of awareness about e-learning resources and compulsory ICT and Digital literacy training for teachers.
\end{abstract}

Key words: ICT Resources, Digital Literacy, Awareness, Utilization, Secondary School Teachers.

DOI: $10.7176 / \mathrm{JEP} / 12-21-08$

Publication date:July $31^{\text {st }} 2021$

\section{Introduction}

The presence of Covid-19 pandemic has held the whole world at ransom and as a result; there has been a disruption in both social, economic and the educational system. In other to foster learning during the pandemic and to reduce the effect of Covid-19 pandemic, the educational system around the globe has shifted from traditional learning to E-learning or virtual platform. E-learning is not a new concept; however the presence of Covid-19 has brought elearning and virtual leaning to lime light. E-learning literarily means using electronic gadgets to facilitate learning. It involves digital technologies which connects a number of persons together and creates an interactive interface for the purpose of learning. According to Eze et al (2018), e-learning in education is concerned with the holistic in corporation of modern telecommunication equipment and ICT resources into the education system. Over the years, researcher Perks (2013); Slaon 2014; Falana 2015, Adeoye et al 2020;) have argued that e-learning provides better content delivery, interactivity, quality content delivery and confidence of both learners and teachers in the educational sector. Despite the advantages of e-learning, educational sector in Nigeria has not been fully adopted the e-learning platform as medium of instruction (Eze and aja, Eze 2018). As the ravaging effect of the pandemic 
takes its turn on the Nigerian education sector, the Government however, is not prepared for the task ahead in terms of making provision for ICT facilities needed to enhance e-learning. Teachers are not well acquainted with the digital literacy skills needed to ensure quality and smooth learning for the students (Obielodan et al, (2020); Basagekar and Singhavi (2017). In developing countries such as Nigeria, schools are struggling to cope with the new norm of using ICT facilities for teaching and learning, which is as a result of poor of staff training on digital literacy. While their counterpart in developed countries; pull resources together to develop materials that will alleviate the traditional method of teaching and key in the teachers into the 21Century teaching methods required by the changes in the modern society and its daily demands on Information and Communication technology. Bearing in mind that the students are devoid of restriction on information from the internet, the concept of ICT utilization and digital literacy in the educational process has changed the role teachers and students (Vidosavljevic, M. 2020) Therefore, it is pertinent to include digital technology and digital literacy into teacher's training, teacher education and teacher's professional development. Researchers (Eze et al 2018) have opined that E-learning is one of the most significant educational innovations driven by a vast array of technology enabled platforms that provides learners an alternative learning environment compared to the traditional or chalk to talk (, Hu and Hui 2012). ICT is cost and time effective, flexible, convenient in course program delivery as one can learn from home and would not necessarily need to transport to school. Notwithstanding, developing countries are still facing problems utilizing ICTs and adopting E-learning platform for teaching and learning. Researchers identified poor funding, corruption, lack of infrastructures and inadequate training of teachers, Lack of motivation, lack of confidence as major barriers to ICT utilization for teaching in schools (Basargekar \& Singhavi 2017, Kabiru \& Sakiyo 2013; Hassan \&Clement 2012). This paper therefore, is focused on the digital literacy and utilization of ICT facilities for teachers in secondary schools in Awka South, Anambra, and what are the implications during the Covid-19 pandemic era.

\subsection{Statement of Problem}

Teachers worldwide are encouraged and expected to implement Information and Communication Technology (ICT) in instruction as ICT now places high demand on education. However, teachers might find it difficult to know how to use the internet in the classroom. Researchers assert that most teachers in Nigeria lack pedagogical knowledge of effective utilization of ICT resources for teaching in Nigeria (Onasanya, 2010; Yusuf et al 2013, Nwana et al 2017; Yushau \& Nannim, 2018; Adikwu, et al 2018). It was also observed that graduates who are hired to work in companies have difficulties manipulating basic ICT tools (Okolocha \& Onaigho 2015). This is an indication that ICT facilities were not adequately utilized in schools. Students are also seen enrolling for road side computer centers to acquire ICT skills. In 1988, the Federal Government of Nigeria introduced computer education. Despite the National Policy on Education NPE (2004) recognizing ICT as a product of technological change and innovation in education; which called for the integration of computer studies into the curriculum and made computer a compulsory subject in secondary schools, there is still a huge gap in the literacy, availability and utilization of ICT resources in schools.

In recent times, greater attention has been given to e-learning and the richness of its content and resources, especially in the area of teaching and learning. Curriculum implementation central to secondary education and the primary purpose of teaching is to achieve the objectives of instruction (Nwana, 2012). The relationship between curriculum and ICT cannot be overemphasized. According to Tella et. al., (2012), the use of ICT by teachers to 
impact knowledge to students is highly advantageous. It is against this background that this study is carried out to assess the level of teachers' awareness of e-learning resources, their application of the resources in curriculum delivery and the problems encountered with the use of e-learning resources in secondary schools in Awka South, Anambra state of Nigeria.

\subsection{Research Questions}

The following research questions have been formulated to guide this study:

1. Are the teachers in the secondary schools within Awka South digital literate?

2. What is the extent of teacher's awareness of e-learning resources in Awka South LGA?

3. Do the teachers in the secondary schools within Awka South use e-learning resources in curriculum delivery?

4. What are the various problems encountered by the teachers of secondary schools in Awka South in the use of e-learning resources?

\subsubsection{Research Hypotheses}

The following hypotheses postulated for the study are tested at 0.05 levels of significance.

Ho. The teachers in the secondary schools in Awka South LGA are not digital literate.

H1. The teachers in the secondary schools in Awka South LGA are digital literate.

Ho. The teacher's in the secondary schools in Awka South LGA are not aware of e-learning resources.

H1. The teacher's in the secondary schools in Awka South LGA are aware of e-learning resources.

Ho. The teachers in the secondary schools in Awka South do not use e-learning resources in curriculum delivery.

H1. The teachers in the secondary schools in Awka South do use e-learning resources in curriculum delivery.

\subsection{Research Purpose}

The aim of this study is to determine:

1. The digital literacy of secondary school teachers in Awka South, Anambra State

2. The extent of utilization of ICT facilities for instruction delivery.

3. To examine the various problems encountered by the teachers in the secondary schools in Awka South in the use of e-learning resources.

\section{The concept of E-learning}

E-learning can be defined as a learning platform that utilizes information network such as the internet, intranet, extranet whether whole or part for the purpose of instruction delivery. It is a digitally empowered learning which utilizes hardware and software to facilitate student and teacher interactions (Eze et al, 2018). E-learning reforms learning from a traditional obscure face to face learning to an ICT based learning that facilitates students and teachers interaction. It is an important $21^{\text {st }}$ century educational innovations that provide technological platforms that promotes learning. E-learning in education is the wholesome integration of modern telecommunication equipment and ICT resources, particularly the internet, into the education system. Researchers have pointed out the significance of e-learning and posited that it should be incorporated into current teaching and learning (Falana 2015, Olojo et al 2012). E-learning is an important $21^{\text {st }}$ century educational innovations that provide technological platforms that promotes learning (Wang 2009). It gives beneficial outcomes on learner's achievement (Eze et al 2018) and it is more engaging than the traditional approach. Therefore, Effective integration of ICT plays an 
important role in teaching and learning (Basargekar \& Sinhavi, 2017; Obielodan et al, 2020)

Content delivery is the most often cited advantage of e-learning and includes increased accessibility to information, ease in updating content, personalized instruction, ease of distribution, standardization of content, and accountability. E-learning empowers students and teacher to access and share structured contents regularly (Chiaha et al 2013).

Accessibility refers to the user's ability to find what is needed, when it is needed. Improved access to educational materials is crucial, as learning is often an unplanned experience. Updating electronic content is easier than updating printed material. E-learning technologies allow educators to revise their content simply and quickly. However researches have shown that teacher's ICT technological knowhow in Nigerian secondary schools is very low. According to Obielodan et al, (2020), Secondary school teachers have low pedagogical knowledge of the utilization of ICT tools for teaching in Ilorin. This is in concordance with Yusuf et al who pointed out that teachers were incompetent in the utilization of ICTs. He added that it was as a result of inadequate training of teachers. Eze et al, (2018) also points out paucity of training, lack of internet facility and attitude of users as some of the factors influencing utilization of ICT facilities in schools. Basagekar and Singhavi (2017) points out low teacher confidence, lack of motivation, lack of confidence as major barriers to ICT utilization for teaching in schools. For teachers to successfully utilize ICT resources they need to be digitally literate and also they require strategic planning and application of teacher's pedagogical knowledge to the instructional experience (Obielodan et al, 2020).

Digital literacy is very important for teachers to successfully facilitate learning through the e-learning platform. Digital Literacy as defined by Gilster (1997) is the ability to understand and use information in multiple formats from a wide range of sources when it is presented through computers. According to Spires and Bartlett (2012), Digital literacy involves the ability to locate and consume, create and communicate digital content while simultaneously employing a process of critical evaluation. Adikwu (2018) asserts that teachers digital literate, can use computers to simplify teaching and make teaching more effective as well as offer students access to learning material regularly. The use of ICTs has opened new trends in teaching and learning. Therefore, Educational policies should focus on creating innovative change through ICT and equipping present day teachers with the required digital skills suitable for the 21 century education.

The Covid-19 Pandemic has left the entire globe with no other option but to adopt e-learning platform to avoid disrupting the educational process. Developed countries have fully adopted this trending technology which has become a normal in the global village. However developing countries are still striving to meet up with this standard. Researchers have blamed teacher's low digital literacy and scarcity of ICT facilities as major factors militating against proper adoption of this technology. Adikwu (2018) argues that the incompetence of teachers in Nigeria towards ICT technology knowhow has affected their educational standard in meeting up to the global standard. Surprisingly school who has ICT facilities also could not fully adopt the eLearning platform as the teachers lacked the technical skills to pilot the affairs of the digital world. This is why Yusuf (2013) in his study, stated that there is scarcity of ICT utilization in schools. The study further revealed that the number of computers made available in the school is very low. He added that the teachers were incompetent in the utilization as a result of non ICT training for teachers. Studies on assessing the utilization of ICT resources in teaching among business educators in tertiary institutions in south Nigeria by Okolocha et al (2015) reveals that there are few available ICT resources 
and they are rarely utilized by the teachers. It was also recounted that the teachers faced challenges such as electricity power interruption whilst utilizing the ICT resources. In agreement to this, findings from Nwana et al (2017) also shows that ICT resources needed for the teaching of computer education are not made available and the very few available ones are not utilized by the teachers. This leaves us to wonder how students are being thought how to use computers when there are no computers made available in the schools.

Furthermore, Oluwalola and Awodiji (2019) investigated the availability and utilization of E-learning facilities for management and business courses in universities in Kwara state, Nigeria. Findings from the research indicated that there were adequate ICT facilities made available, while the utilization was found to be occasionally used for teaching and learning activities.

The low level of digital literacy in Nigeria and insufficient utilization of ICT facilities has led to poor adoption of the e-learning platform during this covid-19 pandemic era. As other developed countries have conveniently continued their educational process without many hitches through the e-learning platforms, developing countries such as Nigeria are still struggling to get onboard with this digital trend for teaching and learning. The importance of ICT in the educational system cannot be over emphasized. The e-learning platform saves cost on learning infrastructures and creates a platform to comfortably share and access contents from anywhere. It also saves time as teachers and student would not have to transport themselves to school. Therefore, there is need for constant training of new and old staff in the use of ICT as well as weekly supervision of teachers to ensure that they utilize the ICT facilities made available for instructional delivery (Eze et al 2018). This way, the adoption and integration of ICT in the teaching and learning process would be made easier. Also the aim of the Government in providing ICT facilities in schools will be met.

In the course of the review, it was pointed out that ICT and e-learning resources are not available categories in the schools, and the extent of digital literacy and utilization in Anambra has not been properly evaluated since our aims was to investigate secondary school teachers usage in Anambra State.

The empirical study shows significantly that, secondary and tertiary institutions in different parts of Nigeria are yet to be fully equipped with e-learning materials and other related resources for the students and lecturers' use. The teachers also do not possess the skills required to adopt and integrate the ICT and e-learning facilities into teaching and learning. The questions here remains: who is responsible for the under provision of these e-learning resource materials and under trained staff in ICTs usage? Should it be as a result of the low funding of the institutions in Nigeria? Does the school management contribute to this challenge? Should the students be compelled to buying these items themselves in order to benefit from the resources? These and so many other questions this study answered on the course of this research.

\section{Methodology}

The study adopted the descriptive survey design. Descriptive survey design was selected because the study entailed asking a large number of participants' questions (in form of questionnaires) about their opinions and experiences. There was an opportunity to explore and probe the respondents for more information. Two hundred and forty (240) senior class teachers were selected from nineteen (19) public secondary schools in Awka South. A formal questionnaire was constructed and used to collect data from a target group of 240 respondents as adopted.

The instrument was subjected to both face and content validations by experts. The reliability of the instrument was determined using Cronbach Alpha. A reliability co-efficient of 0.78 was obtained, an indication that the instrument 
was reliable for data collection. In distributing the copies of the questionnaire, the researcher with two trained research assistants adopted the technique of non-the-spot distribution and collection. This ensured a $100 \%$ return rate. The data collected were analysed using frequency distribution and percentages.

\section{Data presentation and Analysis.}

As mentioned in the methodology, two hundred and forty (240) copies of questionnaire administered and were retrieved. The necessary analysis was carried out on them and presented as follows:

Analysis of Questionnaire and Respondents' Bio data

Table 1: Breakdown of total Questionnaire administered and returned.

\begin{tabular}{|l|l|l|l|}
\hline $\begin{array}{l}\text { No. of Questionnaire } \\
\text { Administered }\end{array}$ & $\begin{array}{c}\text { Percentage } \\
\text { Administered }\end{array}$ & $\begin{array}{c}\text { No. of Quantity } \\
\text { Returned }\end{array}$ & $\begin{array}{c}\text { Percentage } \\
\text { Returned }\end{array}$ \\
\hline 240 & $100 \%$ & 240 & $100 \%$ \\
\hline Total & $100 \%$ & 240 & $100 \%$ \\
\hline
\end{tabular}

Source: Field Survey, 2020

A sample size of two hundred and forty (240) drawn from entire population of secondary school teachers in public secondary schools in Awka South, Anambra State adopted as sample for this study. At the last count exactly 240 questionnaires, representing $100 \%$ return, were retrieved out of 240 distributed as the adopted sample size.

Table 2: Sex distribution of the respondent

\begin{tabular}{|c|c|c|}
\hline Sex of Respondents & Frequency & Percentage of sex \\
\hline \multirow{2}{*}{ Male } & 146 & $60.83 \%$ \\
\hline Total & $\mathbf{2 4 0}$ & $\mathbf{1 0 0 \%}$ \\
\hline
\end{tabular}

Source: Field survey, 2020

Although the data sought by this research are not sex-emphatic, the policy adopted was to ensure equitable participation by both sexes in the spirit of non-sex discrimination. It was observed however, that in most offices and scenario females were few compared to men. Noteworthy also is that they exhibited lukewarm attitude to accepting the researcher's questionnaire. It was also observed that young female employees as well as middle level management females on the contrary were enthusiastic in accepting to complete the questionnaires, preferring that the researcher wait and collect the completed questionnaire immediately.

Notwithstanding what the researcher did to encourage adequate female participation, the sex distribution was 
still lop-sided in favour of males who had a frequency of 146 respondents, representing $60.83 \%$ as against females with a frequency of 94 , representing $39.17 \%$.

Table 3: Age distribution of the respondent

\begin{tabular}{|c|c|c|}
\hline Age Range & Frequency & Percentage \\
\hline $20-25$ & 55 & $29.92 \%$ \\
\hline $26-35$ & 53 & $22.08 \%$ \\
\hline $36-45$ & 46 & $19.17 \%$ \\
\hline $46-55$ & 83 & $34.58 \%$ \\
\hline 56 and above & 3 & $1.25 \%$ \\
\hline Total & 240 & $100 \%$ \\
\hline
\end{tabular}

Source: Field Survey, 2020

Age range 1-20 was excluded from this study naturally. Therefore, the study was kept within age of reasoning so that arising data are thought-out and valid for the demand of the research.

Thus age range 20 - 25 had a response frequency of 55, representing 29.92\%; $26-35 ; 53$ responses, representing $22.08 \%$; 36 - 45; 46 responses, representing 19.17\%; 46 - 55; 83 responses, representing 34.58\%; while 56 and above had 3 responses, representing $1.25 \%$. This indicates that both distribution and retrieved responses are among the strong, productive and reasoning brackets of the society - the earners of salaries and those working in public sector.

Table 4: Educational qualification of the respondent

\begin{tabular}{|l|l|c|}
\hline Certificates & Frequency & Percentage \\
\hline National Diploma (ND) & 46 & $19.17 \%$ \\
Higher National Diploma (HND) & 53 & $22.08 \%$ \\
National Certificate of Education & 55 & $29.92 \%$ \\
Bachelor's Degree & 83 & $34.58 \%$ \\
Master's Degree & 3 & $1.25 \%$ \\
\hline Total & $\mathbf{2 4 0}$ & $\mathbf{1 0 0 \%}$ \\
\hline
\end{tabular}

Source: Field survey, 2020 
To achieve effective data as input for this research analysis as a policy, the exercise accounted with the educational qualification of the respondents: whether FSLC, SSCE/GCE, NCE, Bachelor Degree, Master's Degree and Others.

Of these, ND had a frequency of 46, representing 19.17\%\%; HND 53, representing 22.08\%; NCE 55, representing 29.92\%; Bachelor degree 83, representing 34.58\% while those with Master's degree and above were 3 representing $1.25 \%$ respectively.

\subsection{Data presentation}

The data collected were presented, analyzed, and interpreted in line with the research questions.

\section{Research Question 1: Are you computer literate?}

Table 5:

\begin{tabular}{|l|l|l|l|l|l|l|}
\hline S/N & DESCRIPTION & YES & $\%$ & NO & $\%$ & TOTAL \\
\hline 1 & Are you digital literate? & 72 & 30 & 168 & 70 & 240 \\
\hline
\end{tabular}

\section{Source: Field survey, 2020}

Table 5 shows teachers' computer literacy. Seventy-two respondents indicated 'yes' which represents $30 \%$ while 168 respondents indicated 'NO' which represents 70\%. This is a clear indication that many teachers in Awka South Local Government Area in Anambra State public secondary schools are not computer literate

Research Question 2: Are you aware of the following e-learning resources?

Table 6:

\begin{tabular}{|l|l|l|l|l|l|l|}
\hline S/NESCRIPTION & YES & $\%$ & NO & $\%$ & TOTAL \\
\hline 1 & Internetle-learning platform & 240 & 100 & & & 240 \\
\hline 2 & Computer & 240 & 100 & & & 240 \\
\hline 3 & Laptop & 240 & 100 & & & 240 \\
\hline 4 & Smart phones & 240 & 100 & & & 240 \\
\hline 5 & Video tutorials & 96 & 40 & 144 & 60 & 240 \\
\hline 6 & E-books & 144 & 60 & 96 & 40 & 240 \\
\hline 7 & E-journals & 72 & 30 & 168 & 70 & 240 \\
\hline 8 & Email facilities & 60 & 25 & 180 & 75 & 240 \\
\hline 9 & Digital library & 48 & 20 & 192 & 80 & 240 \\
\hline 10 & Electronic device for marking multiple choice & 36 & 15 & 204 & 85 & 240 \\
& questions & & & & & \\
\hline 11 & Video conferencing & 48 & 20 & 192 & 80 & 240 \\
\hline 12 & Close circuit television & 48 & 20 & 192 & 80 & 240 \\
& & & & & & \\
\hline
\end{tabular}

\section{Source: Field survey, 2020}

Table 6 shows teachers' awareness of e-learning resources. $100 \%(240)$ of the respondents agreed that they are aware of internet, computer, laptop, and smart phones. $40 \%$ (96) of the respondents are aware of video tutorials while $60 \%$ (144) are not. $60 \%$ (144) of the respondents agreed that they are aware of e-books while $40 \%(96)$ are 
not. $30 \%$ (72) of the respondents said that they are aware of e-journals as against the $70 \%$ (168) who said no. $25 \%$ (60) of the respondents are aware of e-mail facilities while 75\% (180) are not. 15\% (36) of the respondents agreed that they are aware of electronic device for marking multiple choice questions while $85 \%$ (204) are not. 20\% (48) of the respondents said 'yes' to digital library, video conferencing, and close circuit television, while 80\% (192) of them are not. The table above shows that the general awareness about e-learning resources is very low in Awka South, Anambra State.

Research Question 3: Do you use any of the following e-learning resources in class for curriculum delivery?

Table 7:

\begin{tabular}{|c|c|c|c|c|c|c|}
\hline $\mathrm{S} / \mathrm{N}$ & DESCRIPTION & YES & $\%$ & $\mathrm{NO}$ & $\%$ & TOTAL \\
\hline 1 & Internet & 48 & 20 & 192 & 80 & 240 \\
\hline 2 & Computer & 48 & 20 & 192 & 80 & 240 \\
\hline 3 & Laptop & 48 & 20 & 192 & 80 & 240 \\
\hline 4 & Smart phones & 96 & 40 & 144 & 60 & 240 \\
\hline 5 & Video tutorials & + & - & 240 & 100 & 240 \\
\hline 6 & E-books & 24 & 10 & 216 & 90 & 240 \\
\hline 7 & E-journals & 48 & 20 & 192 & 80 & 240 \\
\hline 8 & E-mail facilities & 24 & 10 & 216 & 90 & 240 \\
\hline 9 & Digital library &  & 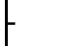 & 240 & 100 & 240 \\
\hline 10 & $\begin{array}{l}\text { Electronic device for marking } \\
\text { multiple choice questions }\end{array}$ & & - & 240 & 100 & 240 \\
\hline 11 & Video conferencing & - & - & 240 & 100 & 240 \\
\hline 12 & Close circuit television & 24 & 10 & 216 & 90 & 240 \\
\hline
\end{tabular}

Source: Field survey, 2020

Table 7 shows teachers' use of e-learning resources for curriculum delivery. $20 \%$ of the respondents answered 'yes' to using internet, computer, and laptop for curriculum delivery, while $80 \%$ answered 'no' to the use of the above resources. $40 \%$ agreed that they use smart phones for curriculum implementation while $60 \%$ said they do not. All the respondents answered no to using video tutorials, electronic device for marking multiple choices question, digital library and video conferencing. Only $10 \%$ of all the respondents answered 'yes' to using e-books, email facilities, and close circuit television while $90 \%$ of them said they do not. $20 \%$ of the respondents said 'yes' to using e-journals for curriculum delivery while $80 \%$ said 'no'. The table shows that the level of application of e-learning resources by secondary school teachers in Awka South LGA in Anambra State is below expectation.

Research Question 4: Do you face the following problems in the utilization of e-learning resources for curriculum delivery? 
Table 8:

\begin{tabular}{|c|c|c|c|c|c|c|}
\hline $\mathrm{S} / \mathrm{N}$ & DESCRIPTION & YES & $\%$ & NO & $\%$ & TOTAL \\
\hline 1 & Lack of internet facilities & 192 & 80 & 48 & 20 & 240 \\
\hline 2 & Lack of fund & 192 & 80 & 48 & 20 & 240 \\
\hline 3 & $\begin{array}{l}\text { Inadequate e- learning resources in } \\
\text { secondary schools }\end{array}$ & 192 & 80 & 48 & 20 & 240 \\
\hline 4 & $\begin{array}{l}\text { High cost of computers, laptops, } \\
\text { smartphones, etc }\end{array}$ & 168 & 70 & 72 & 30 & 240 \\
\hline 5 & Poor electricity supply & 240 & 100 & - & - & 240 \\
\hline 6 & Low level of computer literacy & 144 & 60 & 96 & 40 & 240 \\
\hline
\end{tabular}

Source: Field survey, 2020

Table 8 shows the problems teachers face in the application of e-learning resources in curriculum delivery. $80 \%$ of the respondents said 'yes' to lack of internet facilities, lack of fund, inadequate e-learning resources in secondary schools, and low level of computer literacy while 20\% said 'no'. $70 \%$ said 'yes' to high cost of computer, laptop, smart phones while 30\% said 'no'. All the respondents agreed that poor electricity supply is a problem.

\subsection{Data analysis}

On the issue of computer literacy, the outcome of the study showed that the level of computer literacy of teachers at the secondary schools is very low in Awka South, Anambra state. This finding is in consonance with those of Oluwalola and Awodiji (2019), Adikwu (2018), Nwana (2012); Christopher (2011); and Leonard (2013), all of whom suggested that computer training or training ICT resources be carried out by employers of teachers.

With regards to teachers' awareness of e-learning resources, the study revealed that teachers are aware of elearning resources such as internet, computer, laptop, and smart phones. However, their level of awareness of other resources such as e-books, e-journal, and especially digital library, email facilities close circuit television, video conferencing and electronic device for marking multiple choice questions are still very low. This finding is in line with the recommendation of Oladunjoye and Audu (2014) that intensive seminars, conferences and workshops be organized by relevant bodies to educate and upgrade the technical skills especially in the area of ICT.

In relation to the use of e-learning resources for curriculum delivery, the result revealed that most of the teachers do not use e-learning resources for teaching. The implication of this is that teachers in Awka South, Anambra State are still stocked with the traditional methods of teaching which do not yield good results. This finding agreed with the finding of Nwana (2017) Olatomide W.O. (2012) that most teachers do not use the internet because they do not possess the technical ICT skill required to use e-learning facilities. Also, they do not have computers and they do not have the time to learn about internet. The finding also corroborated the findings of Nwana (2012), Effiong (2005) and Jegede and Owolabi (2003). 
With regards to the problems that teachers face in the use of e-learning resources for curriculum delivery, the study showed that poor electricity supply topped the list while others such as lack of internet facilities, lack of fund, inadequate e-learning resources in secondary school, high cost of computers, and low level of computer literacy formed the other problems. This is in agreement with earlier studies by Leonard Nwana et al (2017); Yushau \& Nannim, (2018), Asogwa (2011) and Leonard (2013). The finding also agreed with the findings and recommendations made Nkasiobi and Helen (2011) that government should among others, tackle the problems of power failure in Nigeria. The study also tallied with that of Adeoye et al, (2020), Philip, et al (2010) that inadequate infrastructure; inadequate skilled man power and funding among others are factors affecting effective usage of e-learning resources.

\subsection{Findings of the study}

The study investigates the extent of awareness and utilization of internet as a source of teaching material among secondary school teachers in Awka South, Anambra State. The outcome of the study showed that the level of computer literacy of teachers at the secondary schools is very low in Awka South, Anambra state. With regards to teachers' awareness of e-learning resources, the study revealed that teachers are aware of e-learning resources such as internet, computer, laptop, and smart phones. However, their level of awareness of other resources such as ebooks, e-journal, and especially digital library, email facilities close circuit television, video conferencing and electronic device for marking multiple choice questions are still very low.

In relation to the use of e-learning resources for curriculum delivery, the result revealed that most of the teachers do not use e-learning resources for teaching. The implication of this is that teachers in Awka South, Anambra State are still stocked with the traditional methods of teaching which do not yield good results. With regards to the problems that teachers face in the use of e-learning resources for curriculum delivery, the study showed that poor electricity supply topped the list while others such as lack of internet facilities, lack of fund, inadequate e-learning resources in secondary school, high cost of computers, and low level of computer literacy formed the other problems.

\subsection{Implications of digital literacy and ICT utilization amidst the COVID-19 Era}

Due to the fast spread of Covid 19, the federal government; just like in other affected countries, ordered the immediate closure of schools at all levels. This was to aid cob the further spread of the virus. All public and private schools were shut down. However this unmasked the inequalities in education. While students in public schools had their education disrupted, their counterparts in top private schools continued learning amidst the pandemic. The private school owners created avenues for online learning while the public schools were less prepared. Most public schools in rural areas lacked ICT facilities and as well teachers with the technological know-how to teach students online. It's worthy to note that this created a huge academic divide amongst private and public schools. This has brought social divide as some students had access to high quality and reliable technology, whereas others did not. Hence Education once again broke down alongside socio economic status. This is why UNESCO (2020) states that "the disadvantage of school closure are enormous for under-privileged students who tend to have fewer or no educational opportunity outside school.

In Nigeria, the low level of digital literacy has disrupted the smooth flow of educational process. Online users faced a lot of difficulties which hindered the teaching and learning process as a result of lack of teacher's technological knowhow. The teachers faced a lot of trouble while working as they lack adequate technical training. 
Students on the other hand also faced challenges such as not being able to access the online lessons as they were not also trained on the utilization of the e-learning facilities. A large number of students whose education was completely disrupted for months due to the COVID-19 pandemic are a great threat to the notional growth. The consequences could be felt in economy and societies in the years ahead (Agbele and Oyalade, 2020).

Covid-19 pandemic is revolutionizing digital and online education globally, but kids in Nigeria are being left behind as they are not equipped to adapt to the new methods of learning. The pandemic has unmasked the inequalities in the education sector. Education and national curriculum reform is a sure way to bridge the gap in inequalities in education. The covid-19 has exposed the digital divide and inequalities amongst learners and compelled the need to reimagine how teachers and educators support student learning (Ana-paula, 2020).

The role of digital literacy in education cannot be over emphasized; therefore there is need to continuously train teachers on ICT skills. Digital literacy is one of the necessary competencies of a modern parson. Acquiring ICT skills is a prerequisite for social inclusion in the 21 st century. Because of the importance of ICT and digital literacy, they have become part of the educational system. The focus on implementing digital literacy is high in many countries as they work towards redesigning their curriculum to suit the contemporary as teachers are confronted with new challenges everyday based on student's needs. Developing the digital skills of teachers is very important to enable them successfully make use of the new methods in the classroom. As stated by Srivastava and Deyb (2018), teacher's needs to acquaint themselves with approaches and application of digital technology, update their skill knowledge and develop their digital literacy. Technological advancement has not only changed teaching and learning, but has also impacted the way people access information, communicate, collaborate and socialize (Hamutoglu, et al 2020).

According to DigCompEdu, (2017), teachers can facilitate learner's digital competence area where students develop collaboration, digital communication, digital content skill, using technologies appropriately. This can only be achieved if the teachers possess the necessary digital skills needed to impart the students with such knowledge. The covi-19 has shown us that we cannot take education for granted. We need to rethink towards alternative approaches for future education; develop ideas and responsive systems and prepare ahead of future shocks. Therefore, Countries must invest in digital infrastructure and digital identity so their citizens can access online services.

\section{Conclusion}

The educational sector, since the inception of e-learning, is undergoing tremendous transformation on daily basis. E-learning itself is a technologically advanced approach to teaching and learning and there is the need for teachers to take advantage of the numerous benefit and opportunities it offers. One way to do this is to become computer literate. Secondly, teachers should seek knowledge of the various e-learning resources available to them. Most importantly, teachers and learners should endeavor to apply the e- learning resources in curriculum implementation. Being computer literate, being able to recognize e-learning resources and being able to apply them in teaching are the key factors in the effective utilization of electronic resources in the present computer age. Anambra state is grappling with problems of students' poor performance in public examinations and there is the need therefore for teachers to embrace e-learning as a better alternative to the traditional mode of teaching.

Increasing awareness and training academic staff on how to use electronic resources is crucial. When this is done, 
it is equally important to make those resources accessible to users by providing constant internet facilities and electricity supply. It is only when users of internet resources fully utilize the resources acquired, that the ICT intention would be realized. The study revealed that awareness and use of e-resources among academic staff of Awka South Local Government Area of Anambra State was not evenly distributed.

\subsection{Recommendations}

The study however, endorses constant training and creates more awareness on electronic databases available in the library. Constant internet should be made available in teachers and students with regular supply of electricity. The public secondary schools should be provided with school Library which will coordinate usage of e-resources and should find an alternative way to generate power supply such as a standby generator, inverter or solar energy system. When researchers are trained regularly, and library resources are made accessible, there may be increased in the use of e-learning materials and there by enhance effective teaching and research development.

Based on the findings, the study recommends the following:

That Anambra State government should, as a matter of urgency, make computer literacy compulsory for all the teachers in her employment,

1. Teachers should be provided soft loans to enable own laptops or desktops computers.

2. Education resource Centre in the state should collaborate with state ministry of education to create awareness about e-learning resources and their usefulness to teachers, students and the entire educational system. Government should, in collaboration with the education resource Centre, organize workshops and seminars on the application of e-learning resources in curriculum delivery.

3. State Government should provide internet facilities in all the secondary schools, provide, alternative source of power supply, for example, solar energy in all secondary schools and take care of the internet access subscription.

4. Government should encourage and put in incentive to attract state, local, international bodies and nongovernmental organizations (NGOs) to invest on ICT related projects in secondary schools.

5. Those teachers that are not ICT compliance should be encourage to study further in order to meet up with the new demand.

6. Attention should be paid to the deploring state of facilities in our secondary schools. Also ICT system together with necessary peripherals should be bought. This will enhance the teaching and learning with e-resource and allow discovery of more facts.

7. Conferences, seminars and workshops and relevant programmes should be organized by professionals of ICT to teach physics teachers and science teachers on modern technology and its uses.

8. ICT relevant curriculum should be developed specially for primary schools, secondary schools and tertiary institutions.

9. Establishing facilities for electronic distance learning networks opportunities in our schools.

10. Creating ICT Application, content and domesticating technology through a conscious Research Design and Development (RD \& D) strategy, advocacy and activities for students.

\section{References}

Agbele, A and Oyelade, E. (2020). Impact of Covid-19 on the Nigerian Educational System: Strenghts and Challenges of Online/Virtual Education. Asian Journal of Educatin and Social Studies (13) 26-35.

Adeoye, I. A. , Adanikin, A. F. , Adanikin, A. (2020). COVID-19 and E-Learning: Nigeria Tertiary Education 
System Experience. International Journal of Research and Innovation in Applied Science (IJRIAS) Volume V, Issue V, May 2020|ISSN 2454-6194.

Adikwu, A. M., Victoria, O., \& Friday, I. (2018). Assessment of Secondary School Teachers'Use of Information and Communication Technology (ICT) in Anyingba Metropolis, Kogi State, Nigeria. 5, 32-47.

Ana-paula, C. (2020). Healing the Digital Divide during the COVID-19 Pandemic. Quarterly Review of Distance Education, v21 n1 p13-21

Asogwa,C.I. (2011). The Challenges of Optimizing E-learning Opportunities for Effective Education Service Delivery in University of Nigeria, Nnsukka, in Nkad, O. and Eze, U. (eds). Optimizing E-learning Opportunities for effective education Service Delivery. A publication of Institute of education, University of Nigeria, Nnsukka.

Basargekar, P. \& Singhavi, C. (2017). Factors affecting teachers' perceived proficiency in using ICT in the classroom. IAFOR Journal of Education, vol. 5, no. 2, pp. 67-84.

Chiaha, G. U, Eze, J.U, Ezeudu, F.O. (2013). Education Student's Access to e-learning facilities in universities South-East of Nigeira. Information and Knowledge Management. 3(10), 32-41

Christopher, O. O. (2011). Information Communication Technology Support for an E-learning Environment at the University of Lagos. Library Philosophy and Practice 6(10).

DigCompEdu (2017). European Framework for the Digital Competency of Educators. Retrieved February 2021

Effiong, J. E. (2005). Business Education in the Era of Information communication Technology: Issues, Problems, and Prospects. Business Education Journals. Vol. 5 (1) pp 3-7.

Eze, S.C. Chinwendu Chinedu-Eze, V C, and Bello, A O. (2018) The utilisation of e-learning facilities in the educational delivery system of Nigeria: a study of M-University. International Journal of Educational Technology in Higher Education. https://doi.org/10.1186/s41239-018-0116-

Gilster, P. (1997). Digital literacy. New York: Wiley and Computer Publishing.

Falana, F. T. (2015.). Prospects And Challenges Of E-Learning In Nigerian University Education Using National Openuniversity Of Nigeria Akure Study Center. Akoko: Department Of Science And Technical Education (Computer Education Unit) Adekunle University Akungba Akoko.

Hamutoglu, N. B., Gemikonakli, O., De Raffaele, C., \& Gezgin, D. M. (2020). Comparative cross-cultural study in digital literacy. Eurasian Journal of Educational Research 88, 121-148. DOI: 10.14689/ejer.2020.88.6

Hu, P. J.-H., \& Hui, W. (2012). Examining the role of learning engagement in technology-mediated learning and itseffects on learning effectiveness and satisfaction. Decision Support Systems,53(4), 782-792.

Jegede, P.O. and Owolabi, A.J. (2003) Computer Education in Nigerian Secondary Schools: Gaps Between Policy and Practice. Meridian: A middle School Technology Journal Vol. 6(2) pp1-11.

Leonard, C. I. (2013) The Assessment of Utilization of E-learning Opportunities for Effective teaching And Learning of Religion in Nigerian Tertiary Institutions. European Journal of Educational Studies. Vol. 5 (3) pp343-359

National Policy on Education. (2014). Federal republic of Nigeria, $7^{\text {th }}$ Edition. NERDC Press.

Nkasiobi, S. A. and Helen, E. A. (2011). Internet and E-learning Technology and the Adult Educator in Nigeria. International Journal of Academic Research in Business and Social Science Vol. 1 (special issue).

Nwana, S. E. (2012). Challenges in the Application of E-learning by Secondary School Teachers in Anambara. African Journal of teacher Education. Vol. 2 (1).

Nwana, S.E, Ofoegbu, T.O, Egbo, C.I (2017). Availability and Utilization of ICT Resources in Teaching Computer Education In Secondary Schools in Anambra State, Nigeria. Mediterranean Journal of Social Sciences. Vol 8(5).

Obieloda, O.O, Omojala, E.A, Tijani, O.K. (2020). Assessment of Teachers 'Pedagogical Knowledge on the Utilization of Information and Communication Technology in Kwara State, Nigeria. International Journal of Education and Development using Information and Communication Technology (IJEDICT), Vol. 16, Issue 1, pp. 62-71.

Okolocha , C.C. and Onaigho, N, C. (2015) . Assessment of Utilization of ICT Resources in Teaching among Tertiary Institution Business Educators in South Nigeria. Journal of Education and Learning. Vol. 4, No.

Olatunjoye,M. I. and Audu,T. S. (2012).The Role of ICT in Entrepreneurship Development. Conference Paper, presented at the $2^{\text {nd }}$ Engineering Conference, Federal Polytechnic, Idah Kogi state

Olatomide, W. O. (2012). An Assessment of Internet Uses, Practices and Barriers for Professional Development by Agricultural Science Teachers in Lagos state. Educational Research International. Vol. 12, Article ID 503264

Olojo, O. J., Adewumi, M. G., \& Ajisola, K. T. (2012). E-learning and its effects on teaching and learning in a 
global age. International Journal of Academic Research in Business and Social Sciences.,2(1), 203-210

Onasanya, S. A., Shehu, R. A., Oduware, R. O., \& Shettu, L. A. (2010). Higher Institutions lecturers' attitude towards integration of ICT into teaching and research in Nigeria. Journal of Information Technology, 2,1-10.

Oluwalola, F, K and Awodiji, O, A (2019). Availability And Utilization Of E-Learning Facilities For Management And Business Courses In Universities In Kwara State, Nigeria. Nigerian Journal of Business Education (NIGJBED) Vol. 6 (2).

Parks, E. (2013). What"s the " $e$ " in e-learning? Ask International.com

Philip, A., et al, (2010). An Evaluation of the Impactof ICT Diffusion in Nigeria's Higher Educational Institutions. Journal of Information Technology Impact. Vol. 10 (1) pp25-34.

Polka, W. S. \& Mattia, P. R. (2009). Curriculum Planning in the Twenty-First Century: Managing Technology, Diversity, and Constructivism to Create Appropriate Learning Environments for All Students. Retrieved Dec. 16, 2020 from http://www.icte.org/T01 Library/T01.

Spires, H., \& Bartlett, M. (2012). Digital literacies and learning: Designing a Path forward. Friday Institute White Paper Series. NC State University.

Srivasta, K, Deyb, S. (2018). Role of Digital technology in Teaching- learning Competency: a survey of Indonasian teachers of English as a foreign language. CALL-EJ, 12(1) 26-42.

Sloan D., Porter E., and Robins K and McCourt K (2014) Using e-learning to support international students'dissertation preparation. Education and Training. Vol 56, No: 2/3, pp.122-140.

Tella, A. A. et al , (2012). An Assessment of Secondary School Teachers' uses of ICTs: Implication for Further Development of ICT's Use in Nigerian Secondary Schools. Savap International, 2 (2). www.savap.org.uk.

UNESCO (2020). 290 Million students out of school due o COVID-19: UNESCO releases first global numbers and Mobilizes response

Vidosavljevic, M. (2020). The Importance of Teacher's Digital Literacy. LEPOSAVITU. ISBN 978-8-8414-3510 p. $415-426$.

Wang, T. (2009). Rethinking teaching with information and communication technologies (ICTs) in architecturaleducation. Teaching Teacher Education.,25(8), 1132-1140.

Yushau, B. and Nannim, F, A. (2018). ICT Facilities and their Utilization for Educational Purpose in Nigerian Universities: A Review of Literature from 2004 to 2018. ATBU, Journal of Science, Technology \& Education (JOSTE); Vol. 6 (1). 